\title{
IMPLEMENTASI METODE DISCOVERY UNTUK MENINGKATKAN MOTIVASI DAN PRESTASI BELAJAR PERTUMBUHAN DAN PERKEMBANGAN TUMBUHAN KELAS XII IPA 1 SMAN 1 BATANGHARI
}

\author{
JONI ALI \\ SMAN 1 BATANGHARI, Kec. Batanghari, Kabupaten Lampung Timur, Lampung \\ e-mail :joniali466@gmail.com
}

\begin{abstract}
The success of learning objectives is determined by many factors, including the teacher's factor in carrying out the teaching and learning process, because teachers can directly influence, foster and improve students' intelligence and skills. To overcome problems and achieve maximum educational goals, the role of educators is very important and has a good and appropriate teaching method / model and is in accordance with the concepts of the subjects to be delivered. The purpose of this study was to determine the effect after the application of discovery learning methods on increasing student learning achievement and motivation. This study used two rounds of action research. Each cycle consists of four stages, namely: design, activity, observation, reflection, and revision. The target of this research is students of class XII IPA 1 SMAN 1 Batanghari with a total of 30 people. The data obtained are in the form of formative test results, observation sheets of teaching and learning activities. From the analysis of the research results, it was found that student achievement and learning motivation had increased from cycle to cycle. The conclusion of this study is the discovery method has a positive effect on learning achievement and learning motivation for Plant Growth and Development in XII IPA 1 students of SMAN 1 Batanghari, as well as being an alternative method of learning Biology which is good.
\end{abstract}

Keywords: Biology Learning, Discovery Method (Discovery)

\begin{abstract}
ABSTRAK
Berhasilnya tujuan pembelajaran ditentukan oleh banyak faktor diantaranya adalah faktor guru dalam melaksanakan proses belajar mengajar, karena guru secara langsung dapat mempengaruhi, membina dan meningkatkan kecerdasan serta keterampilan siswa. Untuk mengatasi permasalahan dan tercapainya tujuan pendidikan secara maksimal, peran pendidik sangat penting dan memiliki cara/model mengajar yang baik dan tepat serta sesuai dengan konsep-konsep mata pelajaran yang akan disampaikan. Tujuan penelitian ini adalah ingin mengetahui pengaruhnya setelah diterapkannya metode pembelajaran discovery terhadap peningkatan prestasi belajar dan motivasi belajar siswa. Penelitian ini menggunakan penelitian tindakan (action research) sebanyak dua putaran. Setiap putaran terdiri dari empat tahap yaitu: rancangan, kegiatan, pengamatan, refleksi, dan refisi. Sasaran penelitian ini adalah siswa kelas XII IPA 1 SMAN 1 Batanghari dengan jumlah 30 orang. Data yang diperoleh berupa hasil tes formatif, lembar observasi kegiatan belajar mengajar. Dari analisis hasil penelitian didapatkan bahwa prestasi maupun motivasi belajar siswa mengalami peningkatan dari siklus ke siklus. Kesimpulan penelitian ini adalah metode discovery (penemuan) berpengaruh positif terhadap prestasi belajar dan motivasi belajar Pertumbuhan dan Perkembangan Tumbuhan pada siswa XII IPA 1 SMAN 1 Batanghari, serta menjadi salah satu alternative metode pembelajaran Biologi yang baik.
\end{abstract}

Kata Kunci: Pembelajaran Biologi, Metode Discovery (Penemuan)

\section{PENDAHULUAN}

Peraturan Pemerintah Nomor 19 tahun 2005 tentang Standar Nasional Pendidikan Pasal 19 ayat 1 menyebutkan bahwa proses pembelajaran pada satuan pendidikan diselanggarakan secara interaktif, inspiratif, menyenangkan, menantang, memotivasi peserta didik untuk berpartisipasi aktif, serta memberikan ruang yang cukup bagi prakarsa, kreativitas, dan 
kemandirian sesuai dengan bakat, minat, dan perkembangan fisik serta psikologis peserta didik.

Proses belajar mengajar merupakan suatu inti dari proses pendidikan secara keseluruhan dengan pendidik sebagai pemegang peran utama. Proses belajar mengajar merupakan suatu proses yang mengandung serangkaian perbuatan pendidik dan siswa atas dasar hubungan timbal balik yang berlangsung dalam situasi edukatif untuk mencapai tujuan tertentu. Interaksi atau hubungan timbal balik antara pendidik dan siswa itu merupakan syarat utama bagi berlangsungnya proses belajar mengajar (Usman, 2000:4). Berhasilnya tujuan pembelajaran ditentukan oleh banyak faktor diantaranya adalah faktor pendidik dalam melaksanakan proses belajar mengajar, karena pendidik secara langsung dapat mempengaruhi dalam membina dan meningkatkan kecerdasan serta keterampilan siswa.

Untuk mengatasi permasalahan di atas dan mencapai tujuan pendidikan secara maksimal, peran pendidik sangat penting dan diharapkan memiliki metode mengajar yang baik dan mampu memilih model pembelajaran yang tepat dan sesuai dengan konsep-konsep mata pelajaran yang akan disampaikan. Untuk itu diperlukan suatu upaya dalam rangka meningkatkan mutu pendidikan dan pengajaran salah satunya adalah dengan memilih strategi pembelajaran agar diperoleh peningkatan prestasi belajar siswa khususnya pelajaran Biologi. Misalnya dengan membimbing siswa untuk bersama-sama terlibat aktif dalam proses pembelajaran dan mampu membantu siswa berkembang sesuai dengan taraf intelektualnya dan menguatkan pemahaman konsep-konsep yang diajarkan. Pemahaman ini memerlukan minat dan motivasi dari dalam diri siswa. Tanpa adanya minat, siswa tidak mempunyai motivasi untuk belajar. Untuk itu, pendidik harus memberikan masukan dalam bentuk motivasi, sehingga dengan bantuan itu anak didik dapat keluar dari kesulitan belajar

Berdasarkan pengalaman penulis di lapangan, kegagalan dalam belajar rata-rata dihadapi oleh sejumlah siswa yang tidak memiliki dorongan belajar. Untuk itu dibutuhkan suatu kegiatan yang dilakukan oleh pendidik sebagai upaya membangkitkan motivasi belajar siswa, misalnya dengan membimbing mereka agar mengalami atau terlibat langsung dalam kegiatan proses belajar mengajar. Motivasi tidak hanya menjadikan siswa terlibat dalam kegiatan akademik, motivasi juga penting dalam menentukan seberapa jauh siswa akan belajar dari suatu kegiatan pembelajaran atau seberapa jauh menyerap informasi yang disajikan kepada mereka Siswa yang termotivasi untuk belajar sesuatu akan menggunakan proses kognitif yang lebih tinggi dalam mempelajari materi itu, sehingga daya serap materi itu lebih baik. Tugas penting pendidik adalah merencanakan bagaimana ia mendukung motivasi siswa (Nur, 20012000:3)Untuk itu sebagai seorang pendidik disamping menguasai materi, juga diharapkan dapat menerapkan dan melaksanakan penyajian materi yang sesuai kemampuan dan kesiapan anak, sehingga menghasilkan penguasaan materi yang optimal bagi siswa.

Metode pembelajaran Discovery merupakan teknik penemuan. Menurut Sund (dalam Malik, 2001:219), discovery adalah proses mental dimana siswa mampu mengasimilasikan sesuatu konsep atau prinsip. Yang dimaksudkan dengan proses mental tersebut antara lain ialah: mengamati, mencerna, mengerti, menggolong-golongkan, membuat dugaan, menjelaskan, mengukur membuat kesimpulan dan sebagainya. Suatu konsep misalnya: segitiga, panas, pertumbuhan, perkembangan demokrasi dan sebagainya, sedang yang dimaksud dengan prisnsip antara lain ialah:makhluk hidup akan tumbuh dan berkembang. Dalam teknik ini siswa dibiarkan menemukan sendiri atau mengalami proses mental itu sendiri, pendidik hanya membimbing dan memberikan instruksi. Dr. J. Richard dan asistennya mencoba self-learning (belajar sendiri) bagi siswa, sehingga situasi belajar mengajar berpindah dari situasi teacher learning menjadi situasi student dominated learning. Dengan menggunakan discovery learning, ialah suatu cara mengajar yang melibatkan siswa dalam proses kegiatan mental melalui tukar pendapat, dengan diskusi, seminar, membaca sendiri dan 
mencoba sendiri. Agar anak dapat belajar sendiri. Penggunaan teknik discovery ini pendidik berusaha meningkatkan aktivitas siswa dalam proses belajar mengajar.

Berdasarkan uraian tersebut di atas penulis mencoba menerapkan salah satu metode pembelajaran, yaitu metode pembelajaran discovery (penemuan) untuk mengungkapkan apakah dengan metode discovery (penemuan) dapat meningkatkan motivasi belajar dan prestasi belajar Biologi. Penulis memilih metode pembelajaran ini mengkondisikan perserta didik untuk terbiasa menemukan, mencari, mendiskusikan sesuatu yang berkaitan dengan pengajaran (Siadari, 2001: 4). Dalam metode pembelajaran discovery (penemuan) siswa lebih aktif dalam memecahkan untuk menemukan sedang pendidik berperan sebagai pembimbing atau memberikan petunjuk cara memecahkan masalah itu. Sementara materi pelajaran Biologi di kelas XII semester 1 ada materi yang cocok untuk dikembangkan menggunakan metode discovery (penemuan) yaitu: Pertumbuhan dan perkembangan tumbuhan. Didalam Kompetensi Dasar (KD) tersebut, siswa diharapkan mampu merancang sebuah percobaan, melaksanakan percobaan dan membuat laporan serta mempresentasikan laporan hasil percobaan pertumbuhan dan perkembangan tumbuhan.

Berdasarkan kenyataan di SMAN 1 Batanghari, pembelajaran materi tersebut tidak menggunakan metode discovery, masih didominasi ceramah sehingga kesannya anak dibatasi taraf berfikirnya, kesempatan mengembangkan kreativitas dan inovasinya. Mayoritas siswanya pasif, jarang ada yang bertanya, sebaliknya jika ditanya tidak ada/sedikit yang mampu menjawab dengan baik dan benar. Sehingga prestasi belajar merekam asih rendah, padahal materi ini tidak sulit dan berkaitan dengan dunia kehidupan siswa sehari-hari Hal ini dapat dilihat dari dokumen nilai ulangan harian tahun pelajaran yang lalu nilai rata-ratanya 58,56 ,nilai KKM yang ditetapkan 70.Terdapat 18 siswa yang mencapai ketuntasan belajar dari 30 orang, dengan interval nilai yang cukup jauhantarasiswa yang sudah tuntas dengan siswa yang belum tuntas.

Dari latar belakang di atas maka penulis dalam penelitian ini mengambil judul: "Implementasi Metode Discovery Untuk Meningkatkan Motivasi dan Prestasi Belajar Pertumbuhan dan Perkembangan Tumbuhan Kelas XII IPA 1 SMAN 1 Batanghari”.

\section{METODE PENELITIAN}

Penelitian ini menggunakan model penelitian tindakan kelas (Classroom Action Research) dari Kemmis dan Taggart (dalam Arikunto\& Suharsimi, 2006:83), yaitu berbentuk spiral dari siklus yang satu ke siklus yang berikutnya.Prosedur penelitian ini diwujudkan dalam bentuk tahapan-tahapan siklus yang berkesinambungan dan berkelanjutan, di mana untuk setiap siklus terdiri dariempat tahapan langkah yang secara garis besar adalah: membuat perencanaan, pelaksanaan,pengamatan/observasi danmelakukan refleksi, termasuk di dalamnya analisis, interpretasi dan evaluasi atastindakan yang telah dilakukan, sehingga bisa diketahui tindakan-tindakan mana yang sudah berhasil sesuai rencana dan tindakan mana yang masih perludiperbaiki lebih lanjut pada siklus berikutnya.Langkah pada siklusberikutnyaadalah

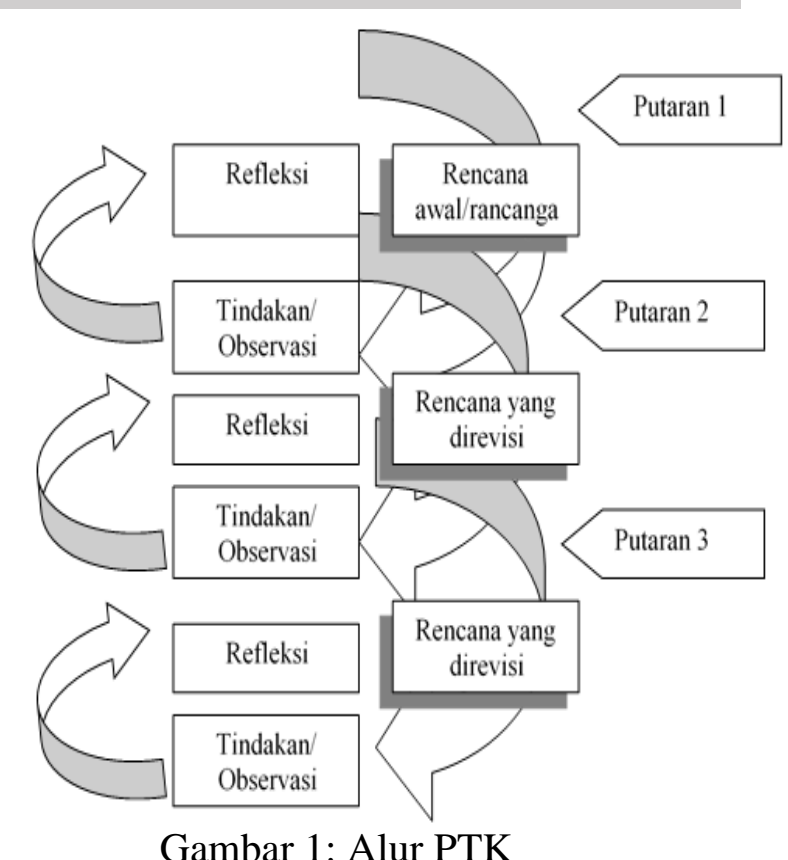
perencanaan yang sudah direvisi, tindakan, pengamatan dan refleksi.Sebelummasuk pada siklus I dilakukan tindakan pendahuluan yang berupa identifikasi permasalahan. Siklus spiral daritahap-tahappenelitiantindakankelasdapatdilihat pada gambar $1 \mathrm{di}$ atas. 
Alat pengumpul data dalam penelitian ini adalah tes buatan pendidik yang fungsinya adalah (1) untuk menentukan seberapa baik siswa telah menguasai bahan pelajaran yang diberikan dalam waktu tertentu, (2) untuk menentukan apakah suatu tujuan telah tercapai, dan (3) untuk memperoleh suatu nilai (Arikunto\& Suharsimi, 2002:149). Selain tes, alatpengumpul data lain yang dipergunakandalampenelitiantindakaniniadalah format observasiberupatabeltabelisian yang telah dipersiapkan dan disusun secara terstruktur dan sistematis, sehingg a pendidik tinggal membubuhkan tanda centang atau check list pada kolom-kolom table isian format observasi yang sesuai dengan aspek pengamatan Di samping itu dipergunakan juga teknik pengumpulan data yang bersifat dokumenter melalui tugas-tugas porto folio dan catatan-catatan pelajaran yang telah dibuat oleh siswa. Teknik analisis data yang relevan dan yang diterapkan adalah teknik analisis deskriptif-kualitatif, menurut (Susilo et al., (2009:19). Indikator keberhasilan penelitian ini dapat dilihat dari sisi proses (penerapan model pembelajaran Discovery) dapat dilihat dari adanya perubahan tingkah laku belajar siswayang relevan (positif) secara signifikan, seperti meningkatnya motivasi belajar, meningkatnya partisipasi belajar siswa, meningkatnya keberanian bertanya dan berpendapat, meningkatnya perhatian siswadalam proses pembelajaran, meningkatnya kemampuan mendengarkan, meningkatnya kreativitas belajar siswa,meningkatnya interaksi belajarsiswa, dan lain sebagainya. Sedangkan keberhasilan dari sisi hasil dapat dilihat dari meningkatnya prestasi belajar siswadan ketuntasan belajarnya secara signifikan sesuai dengan acuan yang telah ditentukan dalam penelitian ini.

Tabel 1.Kriteria Penilaian Prestasi Belajar

\begin{tabular}{ccc}
\hline No & NiIai & Kriteria \\
\hline 1 & $<70$ & Tidak Tuntas (Remidi) \\
2 & $70-80$ & Tuntas dan cukup \\
3 & $81-90$ & Tuntas dan Memuaskan (Pengayaan) \\
4 & $91-100$ & Tuntas dan Sangat Memuaskan (Pengayaan) \\
\hline
\end{tabular}

Tabel 2.Kriteria Aktivitas SiswaYang Tabel 3.Kriteria Aktivitas SiswaYang Tidak Relevan Dengan Belajar

\begin{tabular}{ccc}
\hline No & Nilai/Frekuensi & Kriteria \\
\hline 1 & $<40 \%$ & Rendah Sekali \\
2 & $41-55 \%$ & Rendah \\
3 & $56-70 \%$ & Cukup \\
4 & $71-85 \%$ & Tinggi \\
5 & $86-100 \%$ & Tinggi Sekali \\
\hline
\end{tabular}
Relevan Dengan Belajar

\begin{tabular}{ccc}
\hline No & Nilai/Frekuensi & Kriteria \\
\hline 1 & $1-20 \%$ & Rendah Sekali \\
2 & $21-40 \%$ & Rendah \\
3 & $41-60 \%$ & Cukup \\
4 & $61-80 \%$ & Tinggi \\
5 & $81-100 \%$ & Tinggi Sekali \\
\hline
\end{tabular}

\section{HASIL PENELITIAN dan PEMBAHASAN}

\section{Hasil Penelitian}

Penelitian ini berjalan dalam dua siklus, yang dalam setiap siklusnya berlangsung dua kali pertemuan atau pembelajaran tatap muka (setiap pertemuan $=2 \times 45$ menit) Setiap siklus penelitian terdiri dari 4 (empat) tahap kegiatan utama, yaitu perencanaan, tindakan, pengamatan dan refleksi Data yang dikumpulkan dalam setiap siklus adalah data yang berhubungan dengan motivasi belajar dan prestasi belajar melalui instrumen pengumpul data yang telah ditetapkan, dalam hal ini adalah melalui format observasi dan lembar soal tes yang telah disiapkan oleh pendidik, sesuai menurut Arikunto, Suharsini, (2001 : 149) bahwa alat pengumpulan data dalam penelitian adalah tes buatan pendidik.Berikut ini ditetapkan kisi-kisi indikator keberhasilan dan indikator proses sebagai berikut:

Tabel 4: Kisi-kisi Indikator Keberhasilan

\begin{tabular}{|l|c|c|c|}
\hline No & VariabelMasalah & $\begin{array}{c}\text { Pemecahan } \\
\text { Masalah }\end{array}$ & IndikatorKeberhasilan \\
\hline
\end{tabular}


Vol. 1 No. 1 Mei 2021

\begin{tabular}{|c|c|c|c|}
\hline 1 & $\begin{array}{l}\text { Aktivitas belajar } \\
\text { siswa }\end{array}$ & $\begin{array}{l}\text { Pembelajaran } \\
\text { discovery }\end{array}$ & $\begin{array}{l}\text { 1. Meningkatnya aktivitas belajar siswa sebesar 10-20\% secara } \\
\text { kumulatif dalam aspek-aspek berikut: } \\
\square \text { Keberanian siswadalam bertanya dan mengemukakan } \\
\text { pendapat } \\
\square \text { Motivasi dan kegairahan dalam mengikuti pembelajaran } \\
\text { (menyelesaikan tugas mandiri dan aktif mengerjakan tugas } \\
\text { yang diberikan oleh pendidik) } \\
\square \text { Kerjasama dalam mengerjakan tugas kelompok } \\
\square \text { Kreativitasbelajar (membuat catatan, ringkasan, dan lainnya) } \\
\square \text { Interaksi dengan pendidik selama kegiatan pembelajaran } \\
\square \text { Interaksi dengan sesama siswa selama pembelajaran } \\
\text { (komunikasi dalam kelompok belajar) } \\
\square \text { Partisipasi aktif dalam kegiatan pembelajaran } \\
\text { (memperhatikan dan mendengarkan, ikut melakukan kegiatan } \\
\text { kelompok, selalu mengikuti petunjuk pendidik) } \\
\text { 2. Menurunnya aktivitas yang tidak relevan dengan belajar,sbb: } \\
\square \text { Tidak memperhatikanpenjelasanpendidik } \\
\square \text { Asyik bermain sendiri } \\
\square \text { Melamun dan tidak bergairah belajar } \\
\square \text { Mengobrol sendiri dengan teman dalam proses belajar } \\
\square \text { Mengerjakan tugas lain }\end{array}$ \\
\hline 2 & $\begin{array}{l}\text { Prestasi belajar } \\
\text { siswa }\end{array}$ & $\begin{array}{l}\text { Pembelajaran } \\
\text { discovery }\end{array}$ & $\begin{array}{l}\text { Sebanyak } 85 \% \text { dari siswatelah mencapai ketuntasan belajar sesuai } \\
\text { KKM yang telah ditetapkan, yaitu } 70\end{array}$ \\
\hline
\end{tabular}

Tabel 5: Kisi-kisi Indikator Proses

\begin{tabular}{|c|c|c|c|c|}
\hline No & Variabel Tindakan & Indikator Proses & Urutan Kegiatan & $\begin{array}{l}\text { Instrumen } \\
\text { Pengumpul } \\
\text { an Data }\end{array}$ \\
\hline 1 & $\begin{array}{l}\text { Pembentukan } \\
\text { kelompok blj secara } \\
\text { acakterstruktur }\end{array}$ & $\begin{array}{l}\text { 1. Interaksi dengan } \\
\text { sesama } \\
\text { siswadalam proses } \\
\text { belajar; }\end{array}$ & $\begin{array}{l}\text { 1. Pendidik mengarahkan } \\
\text { pembentukan kelompok } \\
\text { beranggotakan } 6 \text { orang secara } \\
\text { heterogen berdasarkan gender, } \\
\text { sekolah asal, dan kecerdasan }\end{array}$ & $\begin{array}{l}\square \text { Format } \\
\text { observasi } \\
\\
\square \text { Lembar } \\
\text { portofolio } \\
\text { siswa }\end{array}$ \\
\hline 2 & $\begin{array}{l}\text { Pemberian dan } \\
\text { penyematan nama } \\
\text { identifikasi } \\
\text { siswaselama proses; } \\
\text { belajar berlangsung }\end{array}$ & $\begin{array}{l}\text { 2. Kerjasama dalam } \\
\text { mengerjakan tugas } \\
\text { kelompok; }\end{array}$ & $\begin{array}{l}\text { 2. Pendidik membagikan tanda nama } \\
\text { identifikasi yang harus disematkan } \\
\text { pada diri siswaselama proses } \\
\text { belajar di kelas untuk memudahkan } \\
\text { observasi dan penilaian proses; }\end{array}$ & $\begin{array}{l}\square \text { Buku } \\
\text { catatan } \\
\text { pelajaransis } \\
\text { wa }\end{array}$ \\
\hline 3 & $\begin{array}{l}\text { Pemberian tugas } \\
\text { kelompok; }\end{array}$ & $\begin{array}{l}\text { 3. Motivasi dan } \\
\text { kegairahan dalam } \\
\text { proses belajar; }\end{array}$ & $\begin{array}{l}\text { 3. Pendidik menyampaikan kriteria } \\
\text { penilaian hasil dan penilaian proses }\end{array}$ & \\
\hline 4 & $\begin{array}{l}\text { Pendidik memfasilitasi } \\
\text { diskusi kelas; }\end{array}$ & $\begin{array}{l}\text { 4. Keberanian } \\
\text { siswadalam } \\
\text { bertanya dan } \\
\text { mengemukakan } \\
\text { pendapat; }\end{array}$ & $\begin{array}{l}\text { 4. Pendidik memberikan tugas } \\
\text { kelompok dan mengarahkan } \\
\text { perlunya pembagian peran yang } \\
\text { jelas di antara anggota kelompok; }\end{array}$ & \\
\hline 5 & $\begin{array}{l}\text { Pendidik melakukan } \\
\text { tanya jawab tentang } \\
\text { penguasaan materi } \\
\text { dengan seluruh siswa } \\
\text { di kelas; }\end{array}$ & $\begin{array}{l}\text { 5.Kreativitas belajar } \\
\text { siswa (membuat } \\
\text { catatan, ringkasan, } \\
\text { dan lainnya); }\end{array}$ & $\begin{array}{l}\text { 5. Pendidik memfasilitasi dan } \\
\text { membimbing diskusi kelas; }\end{array}$ & \\
\hline 6 & $\begin{array}{l}\text { Pendidik memberikan } \\
\text { post tes tertulis ke-1 } \\
\text { dan ke-2 dan pada } \\
\text { pertemuan selanjutnya } \\
\text { menyampai kan hasil }\end{array}$ & $\begin{array}{l}\text { 6. Interaksi dengan } \\
\text { pendidik selama } \\
\text { kegiatan } \\
\text { pembelajaran; }\end{array}$ & $\begin{array}{l}\text { 6. Pendidik memandu tanya jawab } \\
\text { tentang penguasaan materi; }\end{array}$ & \\
\hline
\end{tabular}




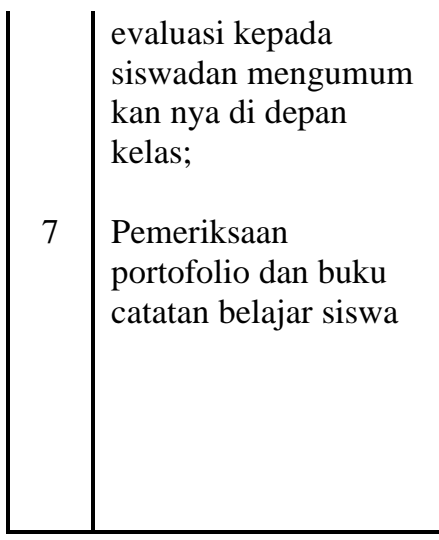

7. Partisipasi aktif siswadalam kegiatan pembelajaran
7. Pendidik membagikan lembar soal post tes ke-1 dan ke-2, dan pada pertemuan berikutnya membagikan dan mengumumkan hasilnya kepadasiswa;

8. Pendidik memeriksa hasil portofolio dan buku catatan pelajarananak

Indikator keberhasilan dan indikator proses yang telah ditetapkan tersebut, dengan sendirinya juga merupakan criteria penerimaan ataupun penolakan hipotesis penelitian (tindakan) yang telah dirumuskan di bagian awal penelitian. Hasil Observasi terhadap aktivitas belajar siswa dari siklus ke siklus setelah diolah dapat dilihat pada tabel 6 :

Tabel 6. Data kualitas Belajar Siswa $(\mathrm{N}=30)$

\begin{tabular}{|c|c|c|c|c|c|}
\hline \multirow{3}{*}{ No } & \multirow{3}{*}{ INDIKATOR PROSES } & \multicolumn{4}{|c|}{ Ketercapaian } \\
\hline & & \multicolumn{2}{|c|}{ Siklus I } & \multicolumn{2}{|c|}{ Siklus II } \\
\hline & & $\mathbf{F}$ & $\%$ & $\mathbf{f}$ & $\%$ \\
\hline 1 & Keberanian peserta didik bertanya dan mengemukakan pendapat & 18 & 60,00 & 25 & 83,33 \\
\hline 2 & $\begin{array}{l}\text { Motivasi dan kegairahan dalam proses belajar (menyelesaikan } \\
\text { tugas mandiri dan tugas kelompok }\end{array}$ & 12 & 40,00 & 23 & 76,67 \\
\hline 3 & Kerjasama dalam kelompok & 18 & 60,00 & 26 & 86,67 \\
\hline 4 & Kreativitas belajar peserta didik (membuat catatan, ringkasan) & 16 & 53,33 & 25 & 83,33 \\
\hline 5 & $\begin{array}{l}\text { Interaksi dan komunikasi dengan sesama peserta didik selama } \\
\text { pembelajaran (dalam kelompok kerja) }\end{array}$ & 16 & 53,33 & 24 & 80 \\
\hline 6 & $\begin{array}{l}\text { Interaksi dan komunikasi dengan pendidik selama kegiatan } \\
\text { pembelajaran }\end{array}$ & 13 & 43,33 & 28 & 93,33 \\
\hline \multirow[t]{2}{*}{7} & $\begin{array}{l}\text { Partisipasi peserta didik dalam pembelajaran (memperhatikan,dan } \\
\text { mendengarkan,, selalu mengikuti petunjuk pendidik) }\end{array}$ & 17 & 56,67 & 28 & 93,33 \\
\hline & Rata-rata & 15,71 & 52,38 & 25,57 & 85,24 \\
\hline
\end{tabular}

Berdasarkan data pada tabel 6 tersebut diketahui bahwa aktivitas belajar siswa mengalami peningkatan dari $52,38 \%$ pada siklus I meningkat menjadi $85,24 \%$ pada siklus II, yang berarti mengalami peningkatan sebesar 32,86\%. Selanjutnya, bagaimana data aktivitas siswa yang kurang relevan dengan pembelajaran, dapat dilihat pada tabel 7 berikut ini !

Tabel 7 Data Aktivitas Siswa Yang Kurang Relevan Dengan Pembelajaran(N = 30)

\begin{tabular}{|c|c|c|c|c|c|}
\hline \multirow{3}{*}{ No } & \multirow{3}{*}{ INDIKATOR PROSES } & \multicolumn{4}{|c|}{ Ketercapaian } \\
\hline & & \multicolumn{2}{|c|}{ Siklus I } & \multicolumn{2}{|c|}{ Siklus II } \\
\hline & & $\mathrm{f}$ & $\%$ & $\mathrm{f}$ & $\%$ \\
\hline 1 & Asyik bermain sendiri & 11 & 36,7 & 5 & 16,7 \\
\hline 2 & $\begin{array}{l}\text { Tidak/kurang memperhatikan penjelasan dari guru atau } \\
\text { teman sekelas }\end{array}$ & 15 & 50,0 & 4 & 13,3 \\
\hline 3 & Mengobrol dan bercanda sendiri dengan teman & 12 & 40,0 & 4 & 13,4 \\
\hline 4 & Melamun dan kurang bergairah belajar & 14 & 46,7 & 6 & 20,0 \\
\hline \multirow[t]{2}{*}{5} & Mengerjakan tugas pelajaran lain & 6 & 20,0 & 2 & 6,7 \\
\hline & Rata-rata & 8,3 & 27,6 & 3,0 & 10,0 \\
\hline
\end{tabular}


Berdasarkan data pada tabel 7 diatas terlihat bahwa aktivitas siswa yang kurang relevan dengan kegiatan pembelajaran mengalami penurunan, dari $27,6 \%$ pada siklus I menjadi $10 \%$ pada siklus II, yang berarti mengalami penurunan sebesar $17,6 \%$ pada akhir siklus II. Selanjutnya, prestasi belajar dan atau ketuntasan belajar siswa terhadap materi pokok pembelajaran Pertumbuhan dan Perkembangan Tumbuhan setelah data diolah dan disederhanakan dapat dilihat pada tabel 8 berikut ini (Data mentahnya dapat dilihat pada Lampiran 8).

Tabel 8.Data Rekapitulasi Prestasi Belajar Siswa (siklus I dan II)

\begin{tabular}{|c|c|c|c|c|c|}
\hline \multirow{3}{*}{ No } & \multirow{3}{*}{ Kriteria Penilaian } & \multicolumn{4}{|c|}{ Ketercapaian } \\
\hline & & \multicolumn{2}{|c|}{ Siklus I } & \multicolumn{2}{|c|}{ Siklus II } \\
\hline & & $f$ & $\%$ & $f$ & $\%$ \\
\hline 1 & Tidak Tuntas (Remidi) & 9 & 30,0 & 2 & 6,7 \\
\hline 2 & Tuntas & 13 & 43,3 & 18 & 60,0 \\
\hline 3 & Tuntas Memuaskan (Pengayaan) & 7 & 23,3 & 8 & 26,7 \\
\hline 4 & $\begin{array}{l}\text { Tuntas Sangat Memuaskan } \\
\text { (Pengayaan) }\end{array}$ & 1 & 3,3 & 2 & 6,7 \\
\hline & $\mathbf{N}=\mathbf{3 0}$ & 30 & & 30 & \\
\hline
\end{tabular}

Dari data pada tabel 8 di atas dapat diketahui bahwa prestasi belajar dan atau ketuntasan belajar siswa dari siklus I ke siklus II cenderung mengalami peningkatan yang relatif besar. Dari 9 siswa $(30 \%)$ yang tidak tuntas pada siklus I menurun menjadi hanya 2 siswa $(6,7, \%)$ yang tidak tuntas dan memerlukan remidi pada akhir siklus II Seiring dengan itu jumlah siswa yang tuntas tetapi tidak perlu pengayaan juga meningkat, dari 13 siswa $(43,3 \%)$ pada siklus I meningkat menjadi 18 siswa (60\%) pada siklus II.Siswa dalam kategori tuntas tetapi tidak memerlukan pengayaan ini merupakan jumlah yang terbesar dalam sebaran distribusi. Berikutnya adalah siswa yang "tuntas dengan predikat memuaskan" dan "sangat memuaskan", masing-masing sebanyak $7(23,3 \%)$ dan $8(26,7 \%)$ pada siklus I dan hanya meningkat sedikit pada akhir siklus II, sangat memuaskan yaitu masing-masing menjadi $1(3,3 \%)$ dan $2(6,7 \%)$. Baik yang tuntas memuaskan maupun yang tuntas sangat memuaskan, keduanya adalah termasuk kategori siswa yang perlu mendapat program pengayaan. Jumlah siswa dalam kategori yang terakhir itu secara kumulatif pada akhir siklus II adalah sebanyak 10 siswa $(33,3 \%)$

\section{Pembahasan Hasil}

Hakikat IPA. IPA didefiniksan sebagai suatu kumpulan pengetahuan yang tersusun secara dalam. Perkembangan IPA tidak hanya ditandai dengan adanya fakta, tetapi juga oleh adanya metode ilmiah dan sikap ilmiah. Metode ilmiah dan pengamatan ilmiah menekankan pada hakikat IPA. Secara rinci hakikat IPA menurut Bridgman dalam (Lestari, 2002:7)adalah : 1). Observasi dan Eksperimen:merupakan salah satu cara untuk dapat memahami konsep-konsep IPA secara tepat dan dapat diuji kebenarannya. 2). Ramalan (prediksi): merupakan salah satu asumsi penting dalam IPA bahwa misteri alam raya ini dapat dipahami dan memiliki keteraturan. Dengan asumsi tersebut lewat pengukuran yang teliti maka berbagai peristiwa alam yang akan terjadi dapat diprediksikan secara tepat. 3). Progresif dan komunikatif: atinya IPA itu selalu berkembang ke arah yang lebih sempurna dan penemuan-penemuan yang ada merupakan kelanjutan dari penemuan sebelumnya.

Proses Belajar Mengajar IPA mengandung pengertian merupakan interaksi semua komponen atau unsur yang terdapat dalam belajar mengajar yang satu sama lainnya saling berhubungan (inter independent) dalam ikatan untuk mencapai tujuan. Belajar diartikan sebagai proses perubahan tingkah laku pada diri individu berkata dan ya interaksi antaraindividudenganlingkungannya. Proses belajarmengajarmerupakansuatu inti dari proses pendidikansecarakeseluruhandenganpendidiksebagaipemegangperanutama. 
Sedangkan menurut buku Pedoman Pendidik Pendidikan Agama Islam, proses belajar mengajar dapat mengandung dua pengertian, yaitu rentetan kegiatan perencanaan oleh pendidik, pelaksanaan kegiatan sampai evaluasi program tindak lanjut (Suryabrata, 1997:18). Dari kedua pendapat tersebut dapat disimpulkan bahwa proses belajar mengajar IPA meliputi kegiatan yang dilakukan pendidik mulai dari perencanaan, pelaksanaan kegiatan sampai evaluasi dan program tindak lanjut yang berlangsung dalam situasi edukatif untuk mencapai tujuan tertentu yaitu pengajaran IPA.

Dari data hasil penelitian yang telah tersaji pada tabel 6, 7, dan 8 tersebut dengan jelas diketahui bahwa aktivitas belajar siswa dalam segala aspek pengamatan mengalami peningkatan yang sangat berarti dari siklus I ke siklus II. Penerapan model pembelajaran discovery melalui tindakan pendidik yang berupa pembentukan kelompok belajar secara acak terstruktur ditambah dengan pemberian dan penyematan tanda nama identifikasi selama proses belajar untuk memudahkan observasi dan penilaian sepertinya cukup bagus untuk menggugah motivasi dan gairah belajarsiswa.Siswa seolah menjadi sangat terkesan dengan penciptaan suasana belajar dan proses penilaian yang tampak serius dan resmi dari pendidik. Mereka berusaha untuk tampil sebaik mungkin dalam rangka mendapat penilaian yang terbaik dari pendidik selama proses pembelajaran. Apalagi setelah mereka mengetahui tentang aturan main dalam penilaian proses maupun penilaian hasil. Hal ini sesuai dengan pendapat Usman, (2004:4) bahwa interaksi (hubungan timbal balik) antara pendidik dan perserta didik merupakan syarat utama bagi berlangsungnya proses belajar mengajar yang baik.

Itulah kiranya yang mendorong siswa untuk (sepertinya berlomba dan terpacu) meningkatkan aktivitas belajar mereka di kelas. Dari yang semula kelihatan pemalu dan pendiam berubah menjadi pro-aktif dalam berinteraksi dan berkomunikasi, baik dengan pendidik maupun dengan teman sekelas atau teman kelompok belajarnya; dari yang semula pemalas, pelamun dan kurangbergairah belajar mendadak menjadi rajin dan bersemangat belajar; dari yang semula kelihatan peragu dan penakut berubah menjadi penuh percaya diri dalam kegiatan tanya jawab; dari yang semula kelihatan "cuek" dan egois berubah menjadi penuh "atensi" dan mau berbagi dengan teman.Hal ini sesuai dengan yang dikemukakan Nur (2001:3) bahwa tugas penting pendidik adalah merencanakan bagaimana ia mendukung motivasi siswa. Begitu juga sesuai dengan pendapat Siadari (2001:4) bahwa pendidik memilih metode pembelajaran yang dapat mengkondisikan siswa untuk terbiasa menemukan, mencari, mendiskusikan sesuatu yang berkaitan dengan pembelajaran.

Motif adalah daya dalam diri seseorang yang mendorongnya untuk melakukan sesuatu, atau keadaan seseorang atau organisme yang menyebabkan kesiapa nya untuk memulai serangkaian tingkah laku atau perbuatan. Sedangkan motivasi adalah suatu proses untuk menggiatkan motif-motif menjadi perbuatan atau tingkah laku untuk memenuhi kebutuhan dan mencapai tujuan, atau keadaan dan kesiapan dalam diri individu yang mendorong tingkah lakunya untuk berbuat sesuatu dalam mencapai tujuan tertentu (Usman, 2000:28).

Sedangkan menurut Djamarah dan Aswan Zain (2002:114) motivasi adalah suatu pendorong yang mengubah energy dalam diri seseorang ke dalam bentuk aktivitasnya atau untuk mencapai tujuan tertentu. Dalam proses belajar, motivasi sangat diperlukan sebab seseorang yang tidak mempunyai motivasi dalam belajar tidak akan mungkin melakukan aktivitas belajar. Hal ini sesuai dengan yang diungkapkan oleh Nur (20012000:3) bahwa siswa yang termotivasi dalam belajar sesuatu akan menggunakan proses kognitif yang lebih tinggi dalam mempelajari materi itu, sehingga siswa itu akan menyerap dan mengendapkan materi itu dengan lebih baik. Jadi motivasi adalah suatu kondisi yang mendorong seseorang untuk berbuat sesuatu dalam mencapai tujuan tertentu.

Hal itu semua terbukti dari data hasil penelitian sebagaimana tersajikan pada tabel 6 di atas, di mana kualitas belajar siswa dalam segala aspek pengamatan dari 52,38\% pada siklus I meningkat menjadi $85,24 \%$ pada akhir siklus II, yang berarti naik sebesar 33,3\%. Berdasarkan kriteria penilaian aktivitas belajar yang telah ditetapkan (lihat tabel 4), prosentase aktivitas belajar sebesar $85,24 \%$ itu tergolong tinggi. Demikian pula angka prosentase kenaikan sebesar $33,3 \%$ tersebut jelas jauh melampaui kriteria keberhasilan penilaian proses sekaligus kriteria pengujian hipotesis yang telah ditetapkan dalam penelitian ini, yakni sebesar $10 \%$. Dengan 
demikian maka hipotesis penelitian (tindakan) pertama yang dirumuskan di bagian terdahulu dalam penelitian ini bisa diterima kebenarannya secara meyakinkan. Hal itu berarti, bahwa "penerapan model pembelajaran discovery pada mata pelajaran Biologi, khususnya pada materi Pertumbuhan dan Perkembangan Tumbuhan terbukti dapat meningkatkan aktivitas belajar siswa Kelas XII IPA 1 Semester I SMAN 1 Batanghari. Hal ini dapat terjadi disebabkan terlebih dahulu adanya perubahan mental pada siswa sebagai dampak penggunaan metode Discovery, sebagaimana yang dikemukakan oleh Sund (.......) dalam Malik (2001:219) bahwa Discovery adalah proses mental siswa yang mampu mengasimilasikan suatu konsep atau prinsip.

Memang harus diakui, bahwa dengan model pembelajaran kooperatif seperti yang diterapkan dalam penelitian tindakan ini suasana belajar di kelas menjadi kesannya agak ramai dan cenderung gaduh. Sesekali sering terdengar suara tepukan meriah dan gelak tawa riang dari para siswa untuk memberikan applause dan support atau karena munculnya spontanitas perilaku jenaka dari teman sekelas ketika berdiskusi ataupun saat mengerjakan tugas-tugas kelompok dan tanya jawab. Meskipun begitu suasana kelas tetap kondusif bagi proses pembelajaran, dan bahkan siswa sepertinya merasakan adanya suasana belajar yang menyenangkan (joyful learning atau learning is fun). Hal ini setidaknya terbukti dari semakin menurunnya secara signifikan aktivitas siswa yang tidak relevan dengan belajar dari siklus I ke siklus berikutnya, sebagaimana terlihat dari sajian data pada tabel 7 di atas, dari 27,6 \% aktivitas siswa yang kurang relevan dengan pembelajaran pada siklus I turun menjadi $10 \%$ pada siklus II. Dan berdasarkan kriteria penilaian yang telah ditetapkan untuk ini (lihat tabel 5), angka prosentase 17,1\% itu tergolong rendah sekali Itu artinya apa? Penerapan tindakan melalui pembelajaran discovery terbukti bisa mereduksi atau mengurangi sampai seminimal mungkin aktivitas siswa yang tidak relevan dengan pembelajaran

Demikian pula halnya bila ditinjau dari segi hasil, data hasil belajar atau prestasi belajar siswa sebagaimana tersajikan pada tabel 8 di atas dengan jelas membuktikan bahwa telah terjadi peningkatan yang sangat signifikan pada prestasi belajarsiswa, dari semula hanya 21 siswa $(13+7+1)$ atau sebesar $70 \%$ yang tuntas belajar pada siklus I meningkat menjadi 28 siswa $(18+8+2)$ atau sebesar 93,3 \% pada akhir siklus II, yang berarti mengalami peningkatan sebesar 23,3\% untuk kategori ini. Sementara itu untuk kategori penilaian hasil yang lain, yakni kategori siswa yang tidak tuntas, dari semula sebanyak 9 siswa(30\%) yang tidak tuntas pada siklus I berkurang secara drastis menjadi hanya 2 siswa $(6,7 \%)$ yang tidak tuntas pada akhir siklus II, yang berarti berkurang sebesar $23,3 \%$. Ternyata benar dan sesuai dengan pendapat BortenBurton dalam (Usman, 2000:5), bahwa seseorang yang telah mengalami proses belajar mengajar yang tepat akan mengalami perubahan tingkah laku aspek pengetahuan, keterampilan maupun sikapnya.

Nawawi dalam (Susanto, 2005\&Ibrahim, 2007). mengemukakan pengertian hasil belajar sebagai keberhasilan murid dalam mempelajari materi pelajaran di sekolah yang dinyatakan dalam bentuk nilai atau skor dari hasil tes mengenai sejumlah pelajaran tertentu.Selanjutnyahasil belajar dibedakan menjadi tiga macam yaitu : a). Hasil belajar yang berupa kemampuan keterampilan atau kecakapan di dalam melakukan atau mengerjakan suatu tugas, termasuk di dalamnya keterampilan menggunakan alat. b). Hasil belajar yang berupa kemampuan penguasaan ilmu pengetahuan tentang apa yang dikerjakan. c). Hasil belajar yang berupa perubahan sikap dan tingkah laku.

Dari berbagai pendapat tersebut dapat disimpulkan bahwa hasil belajar memiliki cakupan makna yang lebih luas dibanding prestasi belajar. Dengan kata lain, prestasi belajar adalah sebagian dari hasil belajar pada mata pelajaran atau materi pelajaran tertentu yang dinyatakan dengan nilai atau angka berdasarkan tes yang dikembangkan dan diberikan oleh pendidik. Meskipun demikian, dalam tulisan ini kedua istilah tersebut dianggap identik dan karenanya bisa saling dipertukarkan pemakaiannya.

Hasil belajar (baca, prestasi belajar) merupakan hasil dari proses yang kompleks. Hal itu disebabkan banyak faktor yang mempengaruhi hasil atau prestasi belajar. Secara garis besar, faktor-faktor yang mempengaruhi hasil atau prestasi belajar itu dibedakan atas dua macam, yaitu faktor dari dalam (internal) diri individu (baca, subyek didik), dan faktor dari luar (eksternal) diri subyek didik. Baik buruknya kualitas kedua faktor ini akan banyak berpengaruh terhadap baik 
buruknya hasil atau prestasi belajar. Semakin baik kondisi atau kualitas kedua faktor tersebut dimiliki oleh subyek didik, maka cenderung semakin baik hasil atau prestasi belajar yang bisa dicapai, dan sebaliknya.Faktor internal, yaitu:Faktor fisiologi, seperti kondisi fisik dan kondisi indera.Faktor Psikologis, meliputi bakat, minat, kecerdasan, motivasi, kemampuan kognitif. Sedangkan faktor eksternal seperti: Faktor lingkungan, seperti keluarga, sekolah, masyarakat, lingkungan alam.Faktor Instrumental, seperti kurikulum, bahan pengajaran, sarana dan fasilitas.

Meskipun angka prosentase kenaikan bagi yang tuntas maupun prosesntase pengurangan bagi yang tidak tuntas dari siklus I ke siklus II tersebut tidak terlalu fantastis, yakni masingmasing 30\% dan 6,7\%, namun bila dihubungkan dengan kriteria keberhasilan yang telah ditetapkan sebelumnya untuk pengujian hipotesis, yakni kenaikan 10\%, maka hal itu sudah lebih dari cukup membanggakan. Terlebih lagi bila dilihat dari segi kriteria keberhasilan secara klasikal yang telah ditetapkan, yakni sebesar 93,33\% dari seluruh siswa dalam kelas harus mencapai ketuntasan belajar, sementara dari penilaian hasil di akhir siklus II ini hanya menyisakan 6,7\% yang tidak tuntas (yang berarti 93,3 \% siswa telah mencapai ketuntasan belajar), maka dari itu dapat dipahami lebih jauh bahwa tindakan pendidik melalui penerapan pembelajaran discovery ini telah berhasil mencapai tujuannya. Dengan demikian hipotesis penelitian (tindakan) kedua yang dirumuskan dalam penelitian ini terbukti dapat diterima kebenarannya secara sah dan meyakinkan. Penerapan model pembelajaran discovery pada pembelajaran Biologi, khususnya pada materi Pertumbuhan dan Perkembangan Tumbuhan terbukti dapat meningkatkan prestasi belajar siswa sebesar 23,3\% (dari semula $70 \%$ yang tuntas pada siklus I bertambah menjadi 93,3\% yang tuntas pada akhir siklus II), dan telah berhasil meningkatkan motivasi belajar siswa sebesar 32,86\% (dari semula 52,38\% pada siklus I menjadi 85,24\% pada akhir siklus II) Kelas XII IPA 1 Semester I SMAN I Batanghari.

\section{KESIMPULAN}

Implementasi metode discovery pada bidang studi Biologi, khususnya materi Pertumbuhan dan Perkembangan Tumbuhan terbukti telah berhasil meningkatkan prestasi belajar dan motivasi belajar siswa Kelas XII IPA 1 Semester I SMAN 1 Batanghari. Dengan demikian maka tindakan pendidik dalam menerapkan model pembelajaran discovery pada bidang studi Biologi di ini telah berhasil mencapai tujuan yang diinginkan.

\section{DAFTAR PUSTAKA}

Arikunto, Suharsini. (2001). Dasar-Dasar Evaluasi Pendidikan. Jakarta: Bumi Aksara.

Arikunto, Suharsini. (2006). Penelitian Tindakan Kelas (Classroom Action Research). Jakarta: Bumi Aksara.

Bridgman, dalamLerstari. (2002). Konsep Dasar dan HakekatIlmuPengetahuanAlam. Jakarta:Penerbit Lestari.

Burton, dalam Usman. (2000). Kendala Yang Dihadapi Guru Dalam Proses BelajarMengajar.Bandung: Remaja Rosdakarya.

Departemen Pendidikan dan Kebudayaan RI. (1990). Kamus Besar Bahasa Indonesia. Jakarta: Balai Pustaka.

Djamarah, S.B.\& Aswan Z. (2002). Strategi BelajarMengajar.Jakarta: Rineka Cipta.

Kemmis, S. \&Mc. Taggart, R. (1988). The Action Research Planner. Victoria Dearcin University Press.

Lestari, Eko Puji. (2002). Pengaruh Strategi Pembelajaran Penemuan Terbimbing melalui Diskusi terhapad Peningkatan Pola Berpikir Kritis dan Kreatif Siswa untuk Pokok Bahasan Dinamika Gerak Lurus. Skripsi yang tidak dipublikasikan. Universitas Negeri Surabaya.

Nawawi dalam Ibrahim,K. (2007. Penelitian dan Penilaian Pendidikan. Bandung: SinarBaru. Nawawi dalam Susanto, A. (2005). Teori Belajar dan Pembelajaran Di Sekolah Dasar. Jakarta: Prenada Media. 
Nur, Moh.(2000). Pendekatan Discovery Dalam Pembelajaran. Yogyakarta: Paradigma.

Pemerintah RI.PP.2005No 19 Pasal 19, Tentang Standar Nasional Pendidikan. Jakarta: Penerbit Cemerlang.

Richard, J.Dr. \& Lockhart dalam Iskandar D. \& Narsim. (2015). Penelitian Tindakan Kelas dan Publikasinya. Cilacap: Ihya Media.

Siadari, (2001). Metode Pembelajaran Penemuan Konsep. Bandung: RemajaRisdakarya.

Sund, R.B.dalamMalik.(2001). Pengertian Model Discovery Learning.Jakarta: Media Pendidikan.

Suryabrata, Sumardi.(1997). PedomanPendidik Pendidikan Agama Islam. Jakarta: Raja GrafindoPersada.

Suryabrata, Sumardi.(1998). Metode Penelitian. Jakarta : Raja GrafindoPersada.

Susilo, Herawati,dkk.(2009).Penelitian Tindakan Kelas Sebagai Sarana Keprofesionalan Guru dan Calon Guru. Malang: Bayumedia.

Usman, Uzer,\& Lilis Setiowati. (2001). Upaya OptimalisasiKegiatanBelajarMengajar. Bandung: RemajaRisdakarya.

Usman, Uzer.(2000). Menjadi Guru Prefosional. Bandung: RemajaRisdakarya. 